Louisiana State University

LSU Digital Commons

Faculty Publications

Department of Chemistry

2-15-2014

\title{
Capillary electrophoresis-based assay of phosphofructokinase-1
}

Andrew Malina

Louisiana State University

Sherrisse K. Bryant

Louisiana State University

Simon H. Chang

Louisiana State University

Grover L. Waldrop

Louisiana State University

S. Douglass Gilman

Louisiana State University

Follow this and additional works at: https://digitalcommons.Isu.edu/chemistry_pubs

\section{Recommended Citation}

Malina, A., Bryant, S., Chang, S., Waldrop, G., \& Gilman, S. (2014). Capillary electrophoresis-based assay of phosphofructokinase-1. Analytical Biochemistry, 447 (1), 1-5. https://doi.org/10.1016/j.ab.2013.10.028

This Article is brought to you for free and open access by the Department of Chemistry at LSU Digital Commons. It has been accepted for inclusion in Faculty Publications by an authorized administrator of LSU Digital Commons.

For more information, please contact ir@lsu.edu. 


\title{
Capillary Electrophoresis-Based Assay of Phosphofructokinase-1
}

\author{
Andrew Malina ${ }^{1,2}$, Sherrisse K. Bryant ${ }^{2}$, Simon H. Chang ${ }^{1}$, Grover L. Waldrop ${ }^{1}$, and S. \\ Douglass Gilman, ${ }^{2}$ \\ ${ }^{1}$ Division of Biochemistry and Molecular Biology, Louisiana State University, Baton Rouge, \\ Louisiana 70803 \\ ${ }^{2}$ Department of Chemistry, Louisiana State University, Baton Rouge, Louisiana 70803
}

\begin{abstract}
An assay was developed for phosphofructokinase-1 (PFK-1) using capillary electrophoresis (CE). In the glycolytic pathway, this enzyme catalyzes the rate-limiting step from fructose-6-phosphate and magnesium-bound adenosine triphosphate (Mg-ATP) to fructose-1,6-bisphosphate and magnesium-bound adenosine diphosphate (Mg-ADP). This enzyme has recently become a research target because of the importance of glycolysis in cancer and obesity. The CE assay for PFK-1 is based on the separation and detection by UV absorbance at $260 \mathrm{~nm}$ of Mg-ATP and MgADP. The separation was enhanced by addition of $\mathrm{Mg}^{2+}$ to the separation buffer. Inhibition studies of PFK-1 by aurintricarboxylic acid and palmitoyl coenzyme A were also performed. An $\mathrm{IC}_{50}$ value was determined for aurintricarboxylic acid, and this value matched values in the literature obtained using coupled spectrophotometric assays. This assay for PFK-1 directly monitors the enzyme-catalyzed reaction, and the CE separation reduces the potential of spectral interference by inhibitors.
\end{abstract}

\section{Keywords}

phosphofructokinase-1; inhibition; capillary electrophoresis; enzyme assay

\section{INTRODUCTION}

Phosphofructokinase-1 (PFK-1) is an allosteric enzyme that catalyzes the ATP-dependent phosphorylation of fructose 6-phosphate (F6P) to fructose 1,6-bisphosphate $(\mathrm{F} 1,6 \mathrm{P})$ as shown in Scheme 1. This reaction is one of the principal regulatory steps in glycolysis [1], and as such PFK-1 is a homotetramer, which allows the activity of the enzyme to be controlled allosterically by the cellular energy level or ATP/AMP ratio [1]. Citrate and ATP act as feedback inhibitors of PFK-1, while AMP, ADP and fructose 2,6-bisphosphate activate the enzyme [2]. The mammalian form of the enzyme has three different isozymes: $\mathrm{M}$ for muscle, L for liver and P for platelets (also called PFK-C) [2; 3]. While most PFK-1 research has focused on its regulatory properties $[1 ; 2 ; 3]$, very little effort has been put into

\footnotetext{
(C) 2013 Elsevier Inc. All rights reserved.

*Address of Corresponding Author: 232 Choppin Hall, Department of Chemistry, Louisiana State University, Baton Rouge, LA 70803; phone 225-578-3010; fax 225-578-3465; sdgilman@1su.edu.

Publisher's Disclaimer: This is a PDF file of an unedited manuscript that has been accepted for publication. As a service to our customers we are providing this early version of the manuscript. The manuscript will undergo copyediting, typesetting, and review of the resulting proof before it is published in its final citable form. Please note that during the production process errors may be discovered which could affect the content, and all legal disclaimers that apply to the journal pertain.
} 
developing inhibitors of the enzyme. This is unfortunate given that there are potential medical applications for the inhibition of PFK-1.

PFK-1 is a potential target for the treatment of obesity and infectious disease. A recent report by Getty-Kaushik et al. [4] found that mice deficient in the M isozyme of PFK-1 had significantly decreased fat stores. This suggests that inhibition of muscle PFK-1 could aid in the treatment of obesity, diabetes and metabolic syndrome. In addition, PFK-1 is increased in cancer cells [5] suggesting that PFK-1, as well as the other enzymes involved in glycolysis, is a potential target for anti-cancer drugs [6]. For instance, inhibition of lactate dehydrogenase resulted in inhibited cell growth in both lymphoma and pancreatic cancer by inducing oxidative stress [7]. Glycosylation of PFK-1 with N-acetylglucosamine also plays a role in cancer cell metabolism [8]. Lastly, PFK-1 is being explored as a possible target for the treatment of the parasitic disease, African sleeping sickness (trypanosomiasis) [9].

Despite the fact that inhibition of PFK-1 is therapeutically relevant to several areas of medicine there are very few known PFK-1 inhibitors that are suitable for pharmaceutical applications. This will likely change now that the first three-dimensional structure of a mammalian PFK-1 is available [10], which will enable structure-based drug design to be used for inhibitor development.

One reason for the shortage of PFK-1 inhibitors could be the lack of suitable assays to screen for such inhibitors. Coupled enzyme assays are routinely used to measure PFK-1 activity. For example, the rate of ADP production is determined using pyruvate kinase and lactate dehydrogenase [1], while production of fructose 1,6-bisphosphate can be coupled to aldolase, glycerol-3-phosphate-dehydrogenase and triosephosphate isomerase [11]. While these two assays have proven to be very useful for the study of the allosteric behavior of PFK-1, they have one major shortcoming when it comes to screening for inhibitors. Both assays rely on the absorbance of NADH at $340 \mathrm{~nm}$ as the basis for detection. This is problematic for screening molecules that might inhibit PFK-1 since many of those molecules absorb strongly around $340 \mathrm{~nm}$. Therefore, an assay for PFK-1 that obviates the spectral interference of potential inhibitors would have wide utility. Additionally, there is always a possibility that an inhibitor can act on one of the reactions only used for detection purposes in a coupled enzyme assay.

Capillary electrophoresis (CE) is a separation technique based on differences in the ratio of charge to hydrodynamic radius for analytes in a conductive solution and can be used to analyze enzyme kinetics and inhibition $[12 ; 13]$. Most importantly, because CE is an electrophoretic separation technique, the potential for spectral interference by inhibitors is greatly reduced. Moreover, $\mathrm{CE}$ is also a rapid technique that consumes only a few $\mathrm{nL}$ of sample per measurement, and it can be used to screen for and study enzyme inhibitors [12; $14 ; 15]$. A CE assay was developed recently by Meades et al. to study inhibitors of the carboxyltransferase component of acetyl CoA carboxylase in cases where the inhibitor spectrally interfered with a coupled enzyme assay based on NADH absorbance at $340 \mathrm{~nm}$ [16]. Here we report the development of a CE assay for PFK-1 and show that the assay can detect inhibition of PFK-1 activity with known inhibitors.

\section{MATERIALS AND METHODS}

\section{Chemicals}

Adenosine 5'-triphosphate, adenosine-5'-diphosphate, fructose-6-phosphate, sodium dodecyl sulfate (SDS), aurintricarboxylic acid (ATA) and palmitoyl coenzyme A (PCoA) were obtained from Sigma (St. Louis, MO). Tris(hydroxymethyl)aminomethane hydrochloride (Tris-HCl) was obtained from Promega (Madison, WI, USA). Magnesium chloride was 
from Fisher Scientific (Pittsburgh, PA). All structures are shown in Supplementary Material (Figure S1).

\section{Preparation of PFK-1}

The rabbit muscle PFK-1 used in these experiments was expressed and purified as described by Banaszak et al. [10]. The final purified enzyme was suspended in a $50.0 \mathrm{mM}$ solution of Tris at $\mathrm{pH}$ 8.2. The $\mathrm{pH}$ of the Tris buffer used to suspend the enzyme was adjusted to 8.2 by addition of concentrated phosphoric acid. Small aliquots were made and stored at $4{ }^{\circ} \mathrm{C}$. Using a Bradford assay [17], the final concentration of the PFK-1 was determined to be 0.5 $\mathrm{mg} / \mathrm{mL}$.

\section{Capillary Electrophoresis}

A simple laboratory-constructed CE instrument was used for all experiments and is similar to instruments described previously [18]. Fused-silica capillary (50- $\mu \mathrm{m}$ i.d., $360-\mu \mathrm{m}$ o.d.) was purchased from Polymicro (Phoenix, AZ) and cut to $60.0 \mathrm{~cm}$. The polyimide coating was burned $(\sim 1 \mathrm{~cm})$ to make a detection window at $40.0 \mathrm{~cm}$ using The Window Maker ${ }^{\mathrm{TM}}$ (MicroSolv Technology Corp.; Eatontown, NJ). The electrophoretic potential was applied with a Spellman CZE 1000R high voltage power supply (Hauppauge, NY). A potential of $25.0 \mathrm{kV}(417 \mathrm{~V} / \mathrm{cm})$ was used for all experiments. All injections were electrokinetic $(3.0 \mathrm{~s}$ at $25.0 \mathrm{kV})$.

Absorbance detection was performed at $260 \mathrm{~nm}$ using an Acutect $500 \mathrm{UV} / \mathrm{V}$ is detector (Scientific Systems; State College, PA) with an on-column capillary cell. A computer program was written in LabView (Version 7.1, National Instruments) and used for data acquisition at $100 \mathrm{~Hz}$. Data were analyzed using OriginLab 7.5 (Northampton, MA). All separation buffers used were prepared to contain $15.0 \mathrm{mM}$ Tris- $\mathrm{HCl}$ and $30.0 \mathrm{mM}$ SDS. The $\mathrm{pH}$ was adjusted to 8.00 with $1.0 \mathrm{M} \mathrm{KOH}$. The sample buffer used for separation development was the same as the enzyme assay buffer described below except that no PFK-1 was added to the solution. All solutions used for CE experiments were prepared with ultrapure water ( $>18 \mathrm{M} \Omega / \mathrm{cm}$ ) obtained from a Modulab water purification system (U.S. Filter; Palm Desert, CA). All buffers used for CE were filtered using a $0.2 \mu \mathrm{m}$ nylon membrane filter prior to use (Whatman; Hillsboro, OR).

\section{Enzyme assays}

Capillary Electrophoresis Assay-The sample buffer used for CE enzyme assays was based on $15.0 \mathrm{mM}$ Tris- $\mathrm{HCl}$ at $\mathrm{pH} 8.00$, and did not contain SDS. The sample buffer also contained $5.0 \mathrm{mM} \mathrm{MgCl}_{2}, 1.00 \mathrm{mM}$ ATP and $1.00 \mathrm{mM} \mathrm{F6P}$. To initiate the reaction, $5.0 \mu \mathrm{L}$ of $0.5 \mathrm{mg} / \mathrm{mL}$ PFK- 1 was added to give a final concentration of $5 \times 10^{-3} \mathrm{mg} / \mathrm{mL}$ (typically) in a total sample volume of $500 \mu \mathrm{L}$. All reactions were performed in $600 \mu \mathrm{L}$ polypropylene microcentrifuge tubes. For inhibition studies with ATA, the ATA was first suspended in water, and then $\mathrm{KOH}$ was added to a final concentration of $0.02 \mathrm{M}$. The $\mathrm{pH}$ of the solution after $\mathrm{KOH}$ addition was 8.0. When performing the PFK-1 assay with ATA, the ATA was added to the reaction mixture, and then PFK-1 was added to initiate the reaction.

The capillary was conditioned between each run by successively injecting $0.5 \mathrm{M} \mathrm{NaOH}$, ultrapure water, then the separation buffer for 5 min each. The Tris-HCl, SDS and magnesium chloride buffer was then placed into both the inlet and outlet vials. To ensure a stable current in the capillary and a stable baseline in the electropherogram, electrophoresis was performed at $25.0 \mathrm{kV}$ for $5 \mathrm{~min}$ with no analyte before injection. 
Data Analysis-The dose dependence of inhibition of PFK-1 by ATA was fitted by nonlinear regression analysis to Equation 1 to determine the concentration of ATA that inhibits the enzyme activity by $50 \%$.

$$
v_{i} / v_{0}=1 /\left(1+\left(\left[I / I C_{50}\right)\right)\right.
$$

In Equation 1, $v_{i}$ is the enzyme activity at a particular ATA concentration and $v_{0}$ is the activity in the absence of ATA. The concentration of ATA is [I], and $I C_{50}$ is the concentration of ATA that results in 50\% inhibition. Enzyme activity was defined as the ratio of $\mathrm{CE}$ peak areas for $\mathrm{Mg}-\mathrm{ADP} /(\mathrm{Mg}-\mathrm{ATP}+\mathrm{Mg}-\mathrm{ADP})$.

\section{Results and Discussion}

\section{Separation and Detection of Mg-ATP and Mg-ADP}

The overall goal of this study was to develop a simple CE assay with UV absorbance detection for the reaction catalyzed by phosphofructokinase- 1 that directly measures substrate depletion and product formation. The first step in the development of this assay was to separate and detect the substrates and products for the PFK-1 catalyzed reaction (Scheme 1). Fructose 6-phosphate and fructose 1,6-bisphosphate exhibit only weak absorbance in the ultraviolet and would be difficult to detect without derivatization [19]. In contrast, both ATP and ADP have a strong absorption band near $260 \mathrm{~nm}$, and analysis of both molecules by CE has been reported previously [20]. An initial, unsuccessful attempt to separate $1.0 \mathrm{mM}$ ATP and $1.0 \mathrm{mM}$ ADP for this assay using absorbance detection at $260 \mathrm{~nm}$ is presented in Supplementary Material (Figure S2).

The separation buffer for this assay represents a compromise between ideal conditions for the PFK-1 catalyzed reaction and optimal conditions for the CE separation. The first separation buffer used during the development of this assay contained $15.0 \mathrm{mM}$ Tris- $\mathrm{HCl}$ and $30 \mathrm{mM}$ SDS at $\mathrm{pH}$ 8.00. It has been reported that addition of SDS improves the separation of ATP and ADP [20; 21]. Under these conditions (above the SDS critical micelle concentration), the separation is a micellar enhanced capillary electrokinetic chromatography (MEKC) separation [22]. The separation buffer did not initially contain $\mathrm{Mg}^{2+}$ in order to lessen the differences in the ionic strength between the separation buffer and the sample buffer, which did not contain SDS.

The sample buffer also contained $15.0 \mathrm{mM}$ Tris- $\mathrm{HCl}$ at $\mathrm{pH} 8.00$ as well as $5.0 \mathrm{mM} \mathrm{MgCl} 2$. Normally a higher ionic strength buffer (e.g. $50 \mathrm{mM}$ Tris) would be used for the PFK-1 catalyzed reaction as described by Kemp et al. [23], but the conductivity of such buffers would result in a large electrophoretic current and excessive Joule heating that would degrade the separation. Preliminary experiments showed that the PFK-1 catalyzed reaction was substantially slower without $\mathrm{Mg}^{2+}$ in the sample buffer (data not shown). This is because the metal nucleotide complex is the actual substrate for PFK-1 as indicated in Scheme 1 [24; 25], and, therefore, the $\mathrm{MgCl}_{2}$ could not be removed from the sample buffer.

The electropherogram obtained using the initial separation buffer (Figure S2) shows at least four peaks for a separation of ATP and ADP, and the peak shapes are generally poor. The relative sizes and exact shapes of these peaks were not reproducible. It was hypothesized that the unexpectedly large number of peaks was due to the dissociation of complexed MgATP and Mg-ADP when these complexes migrated into the separation buffer, which did not contain $\mathrm{Mg}^{2+}$. Various control experiments (no $\mathrm{Mg}^{2+}$ in the sample buffer, no SDS in the separation buffer, ADP alone and ATP alone) were performed and were consistent with this hypothesis. Removing $\mathrm{Mg}^{2+}$ from the sample buffer was not a satisfactory solution because 
of the resulting slow reaction rate. Ultimately, it was necessary to add $1.00 \mathrm{mM} \mathrm{Mg}^{2+}$ to the separation buffer in order to prevent the dissociation of Mg-ATP and Mg-ADP complexes during separation, and obtain electropherograms like that shown in Figure 1. The electropherogram in Figure 1 has two well-resolved peaks, and the addition of $\mathrm{Mg}^{2+}$ to the separation buffer dramatically improved the reproducibility of the separation.

The effect of addition of $\mathrm{Mg}^{2+}$ and other divalent ions to the separation buffer has been explored for nucleotide separations but has not been applied previously to CE enzyme assays [26; 27]. The Mg-ATP and Mg-ADP peaks are baseline resolved, but they are both distinctly triangular in shape (Mg-ATP fronted, Mg-ADP tailed). These asymmetric peak shapes are not unexpected because of the necessary mismatch between the reaction buffer (sample) and separation buffer [28; 29]. Perfectly matching the reaction buffer and separation buffer is not possible if SDS is used for the separation. If SDS were added to the reaction buffer, PFK-1 would be denatured and would not catalyze the reaction.

Experiments with SDS added to standard solutions of ATP and ADP indicated that SDS was not the primary cause of the assymetric peak shapes. This leaves the difference in $\mathrm{Mg}^{2+}$ concentration between the sample solution $(5 \mathrm{mM})$ and separation buffer $(1 \mathrm{mM})$ as the most likely cause. An alternative approach to reduce the negative impact of metal binding to ADP and ADP on the separation is to add EDTA to the separation buffer [30;31], and this approach has been used in the development of a CE enzyme assay [32].

Quantitative analysis of Mg-ADP and Mg-ATP using this separation method was examined with standard solutions from $10 \mu \mathrm{M}$ to $5 \mathrm{mM}$. Calibration curves from $10 \mu \mathrm{M}$ to $1 \mathrm{mM}$ are presented in the Supplementary Material (Figure S3). These plots show good linearity with limits of quantification of $13 \mu \mathrm{M}$ and $20 \mu \mathrm{M}$ for Mg-ATP and Mg-ADP, respectively. At concentrations above $1 \mathrm{mM}$, the electropherograms began to show more than two peaks for ATP and ADP, similar to separations without $\mathrm{Mg}^{2+}$ in the separation buffer (Figure S2). This is not unexpected when the ATP and ADP concentrations exceeded the $\mathrm{Mg}^{2+}$ concentration in the separation buffer. The migration time reproducibility for $\mathrm{Mg}$-ATP and $\mathrm{Mg}$-ADP (RSD for all injections used to produce the calibration curves) was 3\%.

\section{CE Assay for PFK-1}

A series of electropherograms for an assay of rabbit muscle PFK-1 [10] are shown in Figure 2. The electropherogram for injection just before addition of PFK-1 to the reaction solution (Figure 2A) has one peak for Mg-ATP. Figure 2B shows an electropherogram for an injection $30 \mathrm{~s}$ after the addition of PFK- $1\left(5 \times 10^{-3} \mathrm{mg} / \mathrm{mL}\right)$. A small Mg-ADP peak is apparent at $5.6 \mathrm{~min}$. By $8.0 \mathrm{~min}$ after PFK-1 addition, the Mg-ADP peak (Figure 2C) is much larger than the Mg-ATP peak. The electropherogram at $16.0 \mathrm{~min}$ after addition of PFK-1 (Figure 2D) is almost identical to the electropherogram at 8.0 min, indicating that the reaction was at equilibrium by $8.0 \mathrm{~min}$. These electropherograms show that $\mathrm{CE}$ can be used to monitor PFK-1 activity based on separation and detection of Mg-ATP and Mg-ADP. Fructose 6-phosphate and fructose 1,6-biphosphate do not appear in the electropherograms because they do not absorb significantly at $260 \mathrm{~nm}$.

The time dependence for the PFK-1 catalyzed reaction monitored by CE is shown in Figure $3 \mathrm{~A}$. The reaction proceeded at a linear rate up to approximately 8 min and then began to slow. The ratio, $[\mathrm{Mg}-\mathrm{ADP}] /([\mathrm{Mg}-\mathrm{ATP}]+[\mathrm{Mg}-\mathrm{ADP}])$, was plotted in Figure 3 rather than just the $\mathrm{Mg}$-ADP concentration (based on Mg-ADP and Mg-ATP peak areas). This normalizes the measured Mg-ADP concentration to the total concentration of Mg-ATP and Mg-ADP. This improves precision by reducing the impact of variability in sample injection and is possible because both the substrate and product are determined in this assay. The linearity of ADP production was also examined versus PFK-1 concentration (Figure 3B). The ratio, $[\mathrm{Mg}-\mathrm{ADP}] /([\mathrm{Mg}-\mathrm{ATP}]+[\mathrm{Mg}-\mathrm{ADP}])$, was determined after $1.5 \mathrm{~min}$ based on the experiment 
presented in Figure 3A. The activity of PFK-1 was approximately linear from 0.0015$0.0040 \mu \mathrm{g} / \mu \mathrm{l}$.

\section{Inhibition of PFK-1}

The ability of the CE assay to detect inhibition of PFK-1 was demonstrated using a known inhibitor of the enzyme, aurintricarboxylic acid (ATA) [33]. Aurintricarboxylic acid is a reversible inhibitor of PFK-1 and was reported to have an $\mathrm{IC}_{50}$ of $0.2 \mu \mathrm{M}$ for rabbit liver PFK-1 [33]. Electropherograms presented in Supplemental Material (Figure S4) show the elution of ATP and ADP before addition of PFK-1 (A) and at $30 \mathrm{~s} \mathrm{(B),} 8 \mathrm{~min}$ (C) and $16 \mathrm{~min}$ (D) after addition of PFK-1 with $100 \mu \mathrm{M}$ ATA present in the reaction buffer. Comparison with the electropherograms at the same reaction times in Figure 2 clearly shows strong inhibition by $100 \mu \mathrm{M}$ ATA.

A dose response curve for ATA inhibition of PFK-1 is shown in Figure 4. Measurements were made at $1.5 \mathrm{~min}$ after addition of PFK- $1\left(2.25 \times 10^{-3} \mathrm{mg} / \mathrm{mL}\right)$. At this reaction time, each experiment required 10 min leading to a sample throughput of $6 \mathrm{hr}^{-1}$. The data were plotted as the ratio of $[\mathrm{Mg}-\mathrm{ADP}] /([\mathrm{Mg}-\mathrm{ATP}]+[\mathrm{Mg}-\mathrm{ADP}])$ for the inhibited/uninhibited reaction $\left(v_{i} / v_{0}\right)$ versus the $\log$ of the ATA concentration. After fitting the data by non-linear regression to Equation 1, the $\mathrm{IC}_{50}$ was determined to be $3.9_{2} \pm 0.35 \mu \mathrm{M}$. This value is higher than the $\mathrm{IC}_{50}$ reported by McCune et al. [33]. The rabbit muscle isozyme was used in the work presented in this paper, while McCune et al. used the rabbit liver isozyme [33]. Moreover, the value reported by McCune et al. [33] was measured at $\mathrm{pH} 7.3$, while the current study was conducted at $\mathrm{pH}$ 8.0. Considering that ATA has three carboxyl groups, it is likely that binding of the inhibitor to PFK-1 involves ionic interactions and would be $\mathrm{pH}$ dependent. Finally, the $\mathrm{IC}_{50}$ value measured by the $\mathrm{CE}$ assay is a direct determination of the effect of the inhibitor on PFK-1 based on measurement of both Mg-ATP and Mg-ADP and is uncomplicated by potential interactions of the inhibitor with the coupling enzymes utilized by McCune et al [33]. The results for ATA (Figure 4) show that the CE assay can produce excellent quantitative results for inhibition studies.

One of the end products of fatty acid biosynthesis, palmitoyl-CoA (PCoA), was recently reported to reversibly inhibit PFK-1 [34]. Electropherograms for the inhibition of PFK-1 by $5.0 \mu \mathrm{M}$ PCoA are presented in Supplemental Material (Figure S5). As was the case for ATA, inhibition of PFK-1 is evident based on comparison of the electropherograms in Figure $\mathrm{S} 5$ to those in Figure 2. Attempts to determine an $\mathrm{IC}_{50}$ value like that for ATA (Figure 4) were unsuccessful due to poor reproducibility for the PCoA inhibition experiments. This is most likely due to the low solubility of PCoA in the presence of $\mathrm{Mg}^{2+}$, which has been reported in the literature [35] and observed in the experiments presented here. Unfortunately, $\mathrm{Mg}^{2+}$ cannot be removed from the assay because PFK-1 activity depends on its presence.

\section{CONCLUSIONS}

A simple and effective capillary electrophoretic assay for studying PFK-1 activity and inhibition has been developed. Compared to other common assays for this enzyme, the CE assay does not rely on coupling of the enzyme-catalyzed reaction to a second reaction for detection. This reduces the possibility of false positive results in studies of enzyme inhibition. In addition, the CE separation reduces the possibility of spectral interference by an inhibitor or biological samples [16].

\section{Supplementary Material}

Refer to Web version on PubMed Central for supplementary material. 


\section{Acknowledgments}

This work was supported, in part, by P50AT002776 from the National Center for Complementary and Alternative Medicine (NCCAM) and the Office of Dietary Supplements (ODS) which funds the Botanical Research Center of Pennington Biomedical Research Center and the Department of Plant Biology and Pathology in the School of Environmental and Biological Sciences (SEBS) of Rutgers University. The research was partially supported and ADM was completely supported by NSF (MCB0841134).

\section{References}

1. Uyeda K. Phosphofructokinase. Adv Enz Mol Biol. 1979; 48:193-244.

2. Sola-Penna M, Da Silva D, Coelho WS, Marinho-Carvalho MM, Zancan P. Regulation of Mammalian Muscle Type 6-Phosphofructo-1-kinase and Its Implication for the Control of the Metabolism. IUBMB Life. 2010; 62:791-796. [PubMed: 21117169]

3. Dunaway GA. A Review of Animal Phophofructokinase Isozymes with an Empahsis on their Physiological Role. Mol Cell Biochem. 1983; 52:75-91. [PubMed: 6306441]

4. Getty-Kaushik L, Viereck JC, Goodman JM, Guo ZF, LeBrasseur NK, Richard AMT, Flanagan JN, Yaney GC, Hamilton JA, Tornheim K. Mice Deficient in Phosphofructokinase-M Have Greatly Decreased Fat Stores. Obesity. 2010; 18:434-440. [PubMed: 19779479]

5. Yalcin A, Telang S, Clem B, Chesney J. Regulation of Glucose Metabolism by 6-Phosphofructo-2kinase/fructose-2,6-bisphosphatases in Cancer. Exp Mol Pathol. 2009; 86:174-179. [PubMed: 19454274]

6. Pelicano H, Martin DS, Xu RH, Huang P. Glycolysis Inhibition for Anticancer Treatment. Oncogene. 2006; 25:4633-4646. [PubMed: 16892078]

7. Le A, Cooper CR, Gouw AM, Dinavahi R, Maitra A, Deck LM, Royer RE, Jagt DLV, Semenza GL, Dang CV. Inhibition of Lactate Dehydrogenase A Induces Oxidative Stress and Inhibits Tumor Progression. Proc Natl Acad Sci U S A. 2010; 107:2037-2042. [PubMed: 20133848]

8. Yi W, Clark PM, Mason DE, Keenan MC, Hill C, Goddard WA, Peters EC, Driggers EM, HsiehWilson LC. Phosphofructokinase 1 Glycosylation Regulates Cell Growth and Metabolism. Science. 2012; 337:975-980. [PubMed: 22923583]

9. Lavorato SN, Andrade SF, Silva THA, Alves RJ, Oliveira RB. Phosphofructokinase: Structural and Functional Aspects and Design of Selective Inhibitors. Med Chem Comm. 2012; 3:1219-1227.

10. Banaszak K, Mechin I, Obmolova G, Oldham M, Chang SH, Ruiz T, Radermacher M, Kopperschlager G, Rypniewski W. The Crystal Structures of Eukaryotic Phosphofructokinases from Baker's Yeast and Rabbit Skeletal Muscle. J Mol Biol. 2011; 407:284-297. [PubMed: 21241708]

11. Colombo G, Tate PW, Girotti AW, Kemp RG. Interaction of Inhibitors with Muscle Phosphofructokinase. J Biol Chem. 1975; 250:9404-9412. [PubMed: 127795]

12. Chantiwas, R.; Yan, X.; Gilman, SD. Microfluidics for Studying Enzyme Inhibition. In: Gomez, FA., editor. Biological Applications of Microfluidics. Wiley; Hoboken: 2008. p. 135-170.

13. Hai X, Yang B-f, Van Schepdael A. Recent Developments and Applications of EMMA in Enzymatic and Derivatization Reactions. Electrophoresis. 2012; 33:211-227. [PubMed: 22147291]

14. Nehme H, Nehme R, Lafite P, Routier S, Morin P. New Development in In-Capillary Electrophoresis Techniques for Kinetic and Inhibition Study of Enzymes. Anal Chim Acta. 2012; 722:127-135. [PubMed: 22444544]

15. Yan XY, Gilman SD. Improved Peak Capacity for CE Separations of Enzyme Inhibitors with Activity-Based Detection Using Magnetic Bead Microreactors. Electrophoresis. 2010; 31:346354. [PubMed: 20024913]

16. Meades G, Henken RL, Waldrop GL, Rahman MM, Gilman SD, Kamatou GPP, Viljoen AM, Gibbons S. Constituents of Cinnamon Inhibit Bacterial Acetyl CoA Carboxylase. Planta Med. 2010; 76:1570-1575. [PubMed: 20379951]

17. Bradford MM. Rapid and Sensitive Method for Quantitation of Microgram Quanitities of Protein Utilizing Principle of Protein-Dye Binding. Anal Biochem. 1976; 72:248-254. [PubMed: 942051] 
18. Whisnant AR, Johnston SE, Gilman SD. Capillary Electrophoretic Analysis of Alkaline Phosphatase Inhibition by Theophylline. Electrophoresis. 2000; 21:1341-1348. [PubMed: 10826679]

19. El Rassi Z. Recent Developments in Capillary Electrophoresis and Capillary Electrochromatography of Carbohydrate Species. Electrophoresis. 1999; 20:3134-3144. [PubMed: 10596821]

20. Geldart SE, Brown PR. Analysis of Nucleotides by Capillary Electrophoresis. J Chromatogr A. 1998; 828:317-336. [PubMed: 9916315]

21. Bryant SK, Waldrop GL, Gilman SD. A Capillary Electrophoretic Assay for Acetyl CoA Carboxylase. Anal Biochem. 2013; 437:32-38. [PubMed: 23435309]

22. Terabe S. Capillary Separation: Micellar Electrokinetic Chromatography. Annu Rev Anal Chem. 2009; 2:99-120.

23. Kemp RG, Foe LG, Latshaw SP, Poorman RAP, Heinrikson R. Studies on the Phosphorylation of Muscle Phosphofructokinase. J Biol Chem. 1981; 256:7282-7286. [PubMed: 6265442]

24. Cowan JA. Metallobiochemistry of Magnesium. Coordination Complexes with Biological Substrates: Site Specificity, Kinetics and Thermodynamics of Binding and Implications for Activity. Inorg Chem. 1991; 30:2740-2747.

25. Cowan JA. Structural and Catalytic Chemistry of Magnesium-Dependent Enzymes. Biometals. 2002; 15:225-235. [PubMed: 12206389]

26. Cahours X, Morin P, Dreux M. Capillary Electrophoretic Study of the Complexation of Nucleotides with Magnesium and Calcium Ions. Chromatographia. 1998; 48:739-744.

27. Kawamura K. Capillary Electrophoretic Separation of Mono- and Dinucleotides of Adenosine Using Cyclodextrin Solutions with $\mathrm{MgCl}_{2}$ Additive. J Chromatogr A. 1998; 802:167-177.

28. Foret F, Kleparnik K, Gebauer P, Bocek P. Ionic Boundaries in Biological Capillary Electrophoresis. J Chromatogr A. 2004; 1053:43-57. [PubMed: 15543971]

29. Mala Z, Gebauer P, Bocek P. System Effects in Sample Self-Stacking CZE: Single Analyte Peak Splitting of Salt-Containing Samples. Electrophoresis. 2009; 30:866-874. [PubMed: 19197903]

30. Elisabeth P, Yoshioka M, Sasaki T, Senda M. Separation of Nucleotides Using Micellar Electrokinetic Capillary Chromatography. J Chromatogr A. 1998; 806:199-207.

31. Loregian A, Scremin C, Schiavon M, Marcello A, Palu G. Quantitative Analysis of Ribonucleotide Triphosphates in Cell Extracts by High Performance Liquid Chromatography and Micelar Electrokinetic Capillary Chromatography: A Comparitive Study. Anal Chem. 1994; 66:29812984. [PubMed: 20213951]

32. Kulp M, Kaljurand M, Kaambre T, Sikk P, Saks V. In Situ Monitoring of Kinetics of Metabolic Conversion of ATP to ADP Catalyzed by MgATPases of Muscle Gastrocnemius Skinned Fibers Using Micellar Electrokinetic Chromatography. Electrophoresis. 2004; 25:2996-3002. [PubMed: 15349940]

33. McCune SA, Foe LG, Kemp RG, Jurin RR. Aurintricarboxylic Acid is a Potent Inhibitor of Phosphofructokinase. Biochem J. 1989; 259:925-927. [PubMed: 2525029]

34. Jenkins CM, Yang JY, Sims HF, Gross RW. Reversible High Affinity Inhibition of Phosphofructokinase-1 by Acyl-CoA - A Mechanism Integrating Glycolytic Flux with Lipid Metabolism. J Biol Chem. 2011; 286

35. Constantinides PP, Steim JM. Solubility of palmitoyl-coenzyme A in acyltransferase assay buffers containing magnesium ions. Arch Biochem Biophys. 1986; 250:267-270. [PubMed: 3767379] 


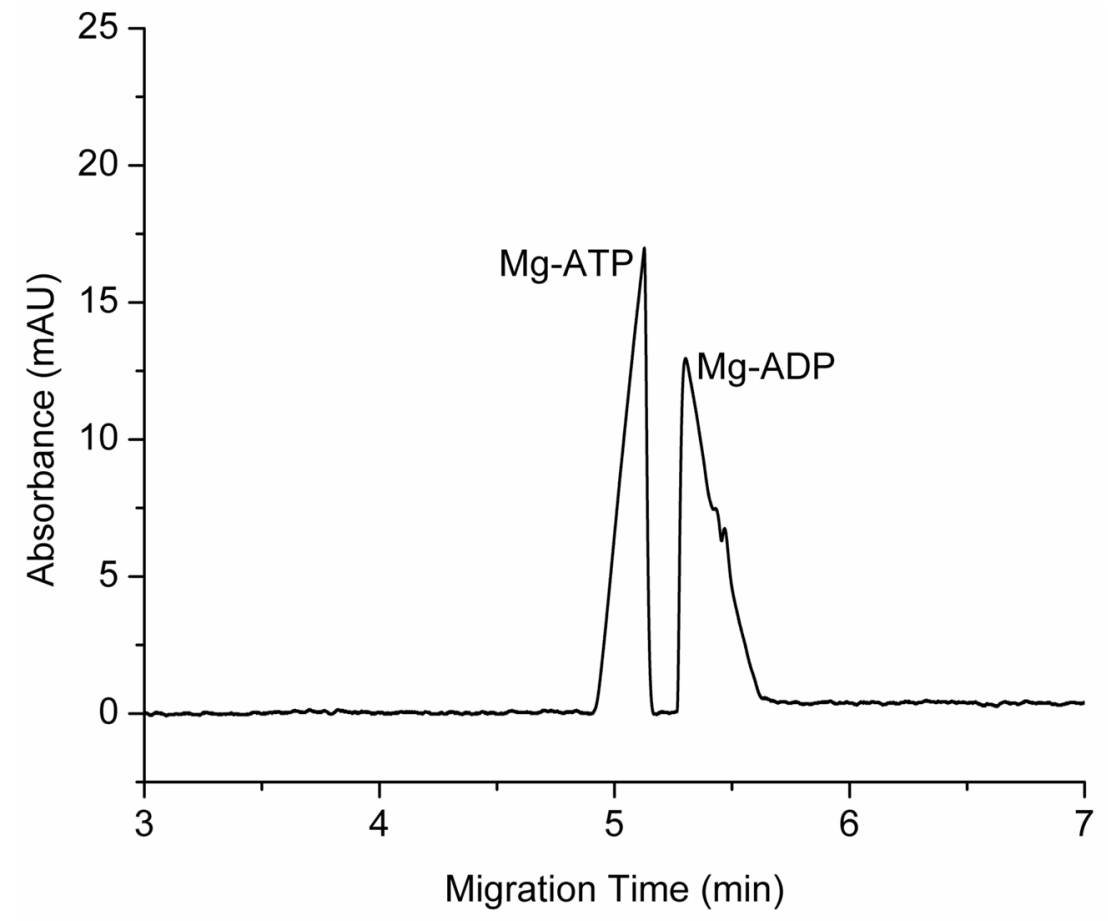

Figure 1.

Electropherogram for the injection of $1.0 \mathrm{mM}$ ATP and $1.0 \mathrm{mM}$ ADP with absorbance detection at $260 \mathrm{~nm}$. The sample was injected electrokinetically for $3.0 \mathrm{~s}$ at $25.0 \mathrm{kV}$ (417 V/ $\mathrm{cm}$ ). The separation buffer was $15.0 \mathrm{mM}$ Tris- $\mathrm{HCl}$ at $\mathrm{pH} 8.00$ with $30.0 \mathrm{mM}$ SDS and 1.0 $\mathrm{mM} \mathrm{Mg}{ }^{2+}$. The sample solution also contained $5.0 \mathrm{mM} \mathrm{Mg}^{2+}$ to mimic conditions required for the PFK-1 assay, but it did not contain SDS. The separation potential was $25.0 \mathrm{kV}$ (417 $\mathrm{V} / \mathrm{cm}$ ), and the electrophoretic current was $25 \mu \mathrm{A}$. 


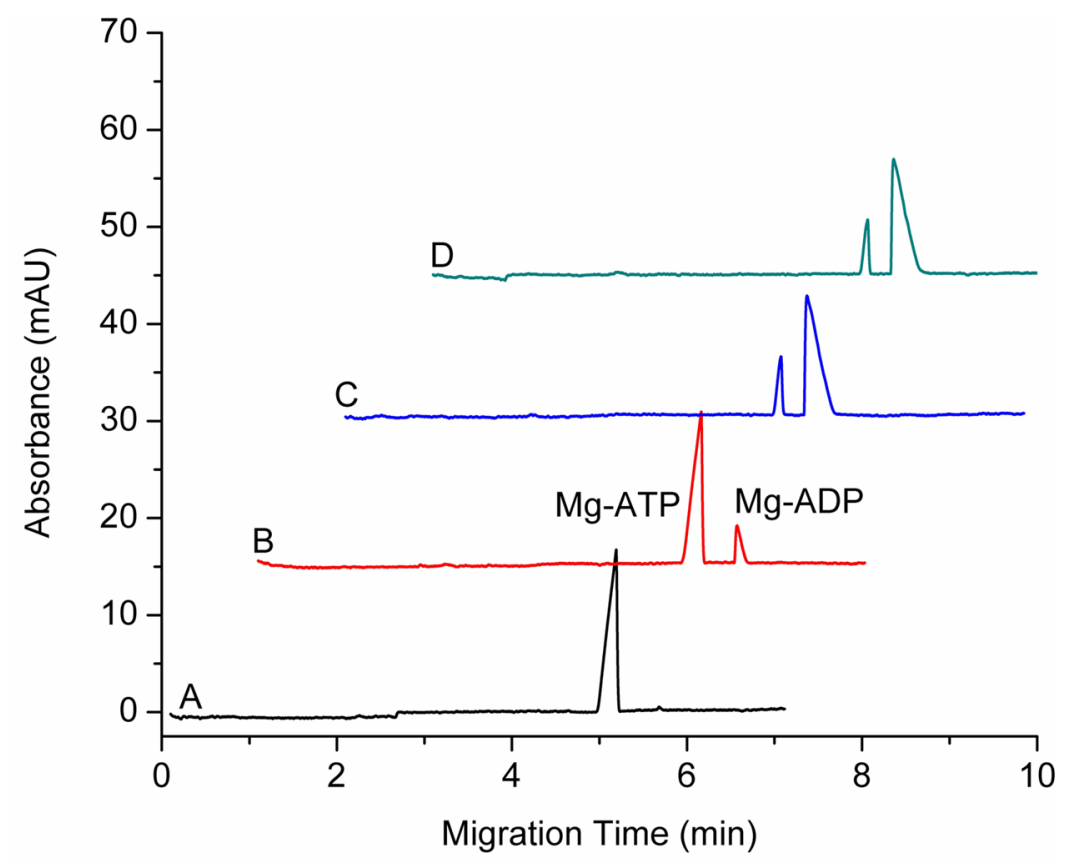

Figure 2.

Electropherograms for the PFK-1 assay. The separation conditions are the same as those used in Figure 1. The reaction/sample buffer was the same as that used in Figure 1 except for the addition of PFK-1 and $1.0 \mathrm{mM}$ fructose 6-phosphate. A, Electropherogram for the reaction mixture just before addition of PFK-1. B, Electropherogram $30 \mathrm{~s}$ after the addition of PFK-1 $\left(5 \times 10^{-3} \mathrm{mg} / \mathrm{mL}\right)$. C, Electropherogram $8.0 \mathrm{~min}$ after the addition of PFK-1. D, Electropherogram 16.0 min after the addition of PFK-1. The electropherograms for B-D were artificially offset for ease of viewing. 

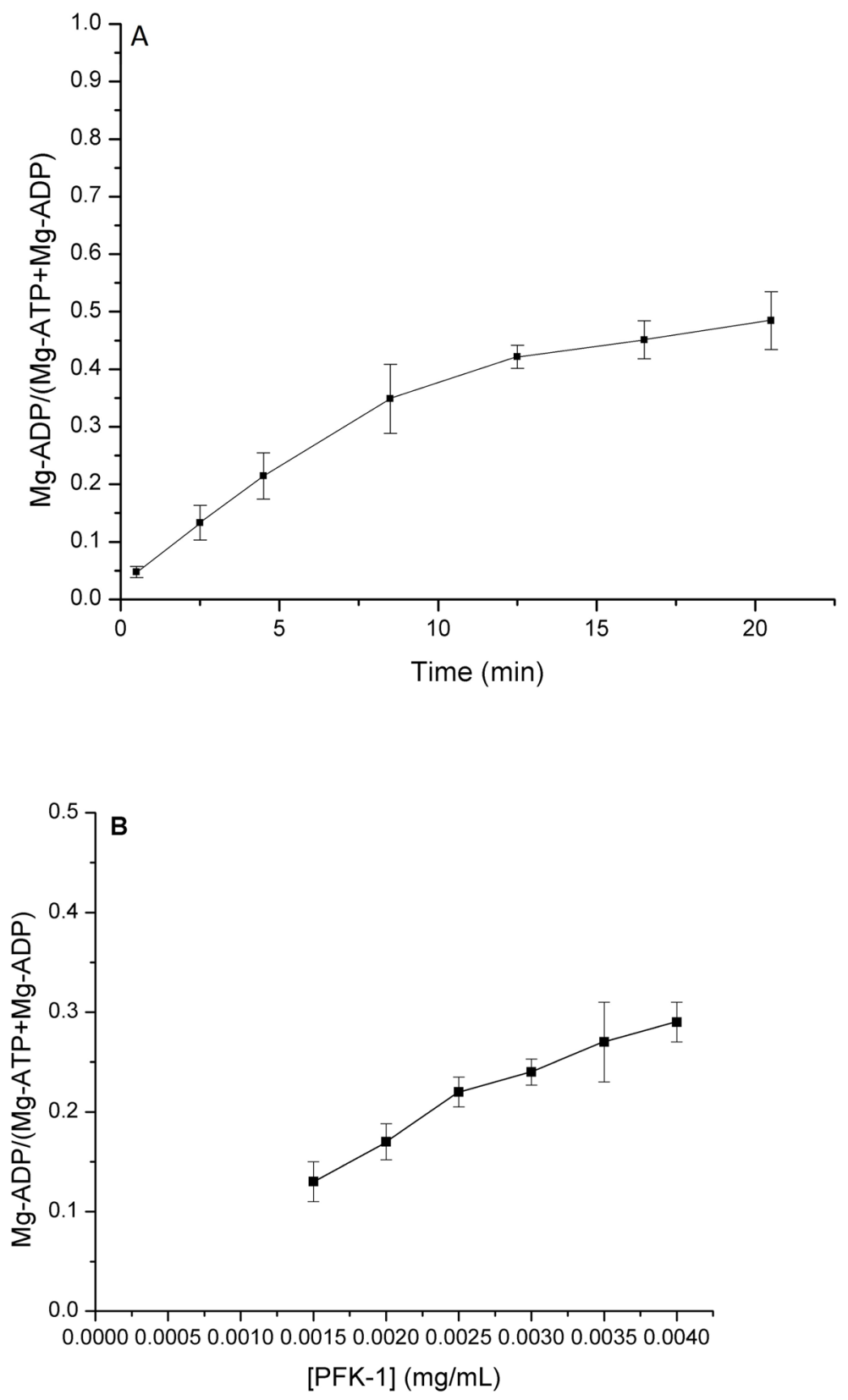

Figure 3.

A, Production of Mg-ADP (reaction rate) for the reaction catalyzed by PFK-1 for reaction times from 0 to $20.5 \mathrm{~min}$. As explained in the text, peak areas were used to determine the plotted ratio $\mathrm{Mg}-\mathrm{ADP} /(\mathrm{Mg}-\mathrm{ATP}+\mathrm{Mg}-\mathrm{ADP})$. All experimental conditions are the same as in Figure 2 except that the PFK-1 concentration was $2.7 \times 10^{-3} \mathrm{mg} / \mathrm{mL}$. B, Production of $\mathrm{Mg}$ ADP (reaction rate) versus PFK-1 concentration. The $\mathrm{Mg}-\mathrm{ADP} /(\mathrm{Mg}-\mathrm{ATP}+\mathrm{Mg}-\mathrm{ADP})$ ratio was measured at a reaction time of $1.5 \mathrm{~min}$. Error bars represent the standard deviation for 3 measurements. 


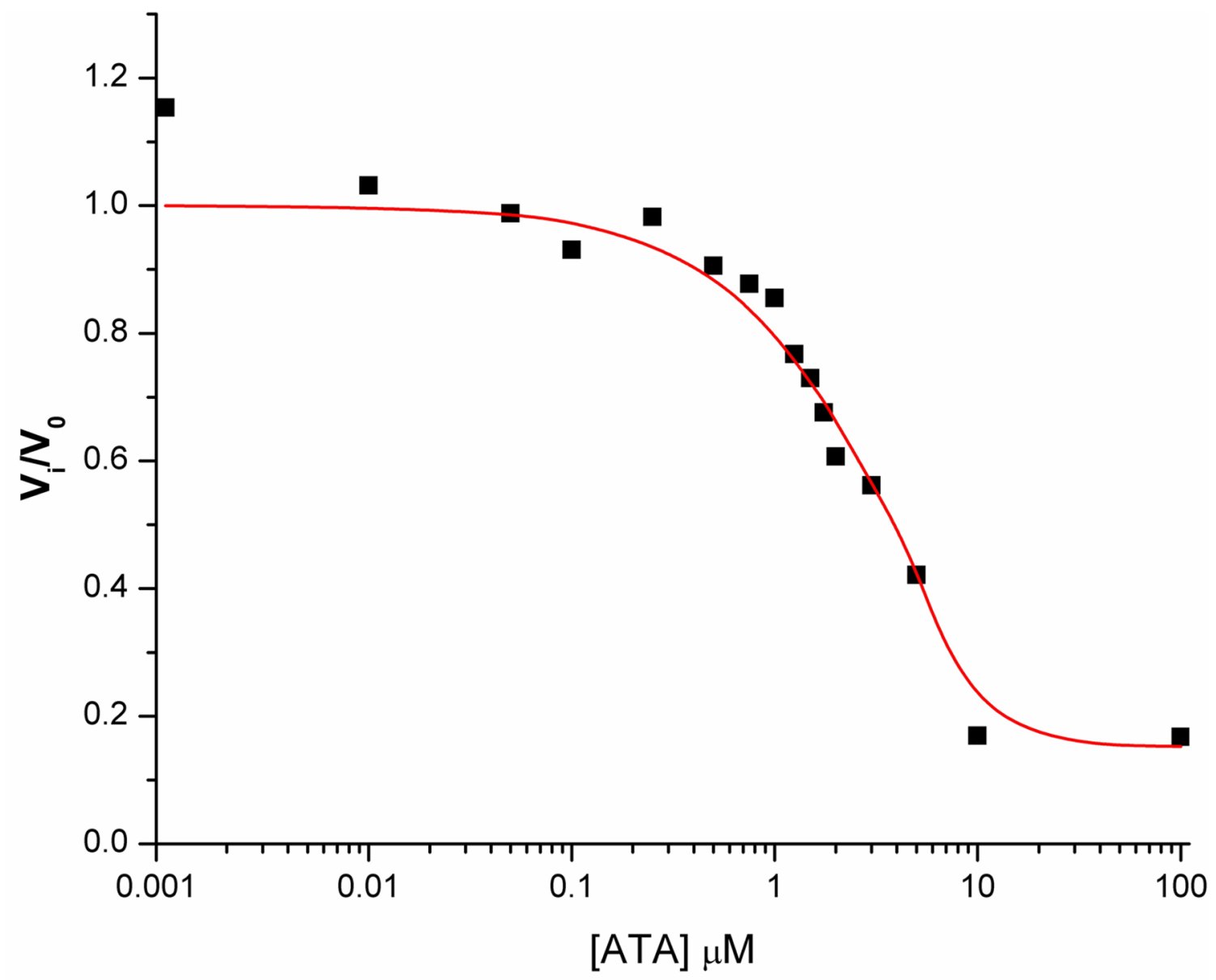

Figure 4.

The dose dependence of PFK-1 inhibition by ATA. The Mg-ADP/(Mg-ATP+Mg-ADP) ratio was measured at $1.5 \mathrm{~min}$ using $2.25 \times 10^{-3} \mathrm{mg} / \mathrm{mL}$ of PFK-1 as function of increasing ATA concentration from $1 \mathrm{nM}$ to $100 \mu \mathrm{M}$ and divided by the value with no ATA to determine $v_{i} / v_{0}$. The plotted points represent the average for three experiments, and the line represents the best fit of the data to Equation 1. 


$$
\text { Fru-6-P + Mg-ATP } \longrightarrow \text { Mg-ADP + Fru-1,6-P }
$$

SCHEME 1. 